Portland State University

PDXScholar

7-23-1979

\title{
Culture and Growth of Closterium ehrenbergii (Desmidiaceae)
}

David Bruce Renstrom

Portland State University

Follow this and additional works at: https://pdxscholar.library.pdx.edu/open_access_etds

Part of the Biology Commons, and the Microbiology Commons

Let us know how access to this document benefits you.

\section{Recommended Citation}

Renstrom, David Bruce, "Culture and Growth of Closterium ehrenbergii (Desmidiaceae)" (1979).

Dissertations and Theses. Paper 2882.

https://doi.org/10.15760/etd.2876

This Thesis is brought to you for free and open access. It has been accepted for inclusion in Dissertations and Theses by an authorized administrator of PDXScholar. Please contact us if we can make this document more accessible: pdxscholar@pdx.edu. 
AN ABSTRACT OF THE THESIS OF David Bruce Renstrom for the Master of Science in Biology presented July 23, 1979.

Title: Culture and Growth of Closterium ehrenbergii (Desmidiaceae)

APPROVED BY MEMBERS OF THE THESIS COMMITTEE:

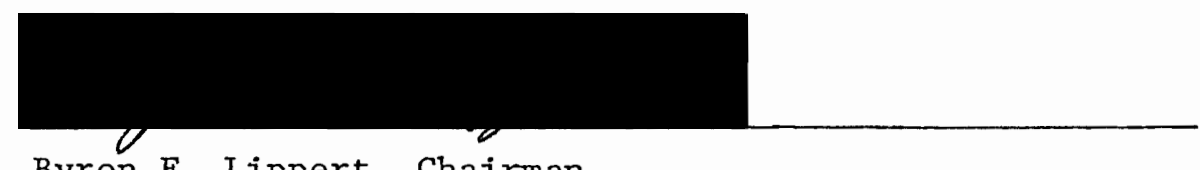

Byron E. Lippert, Chairman
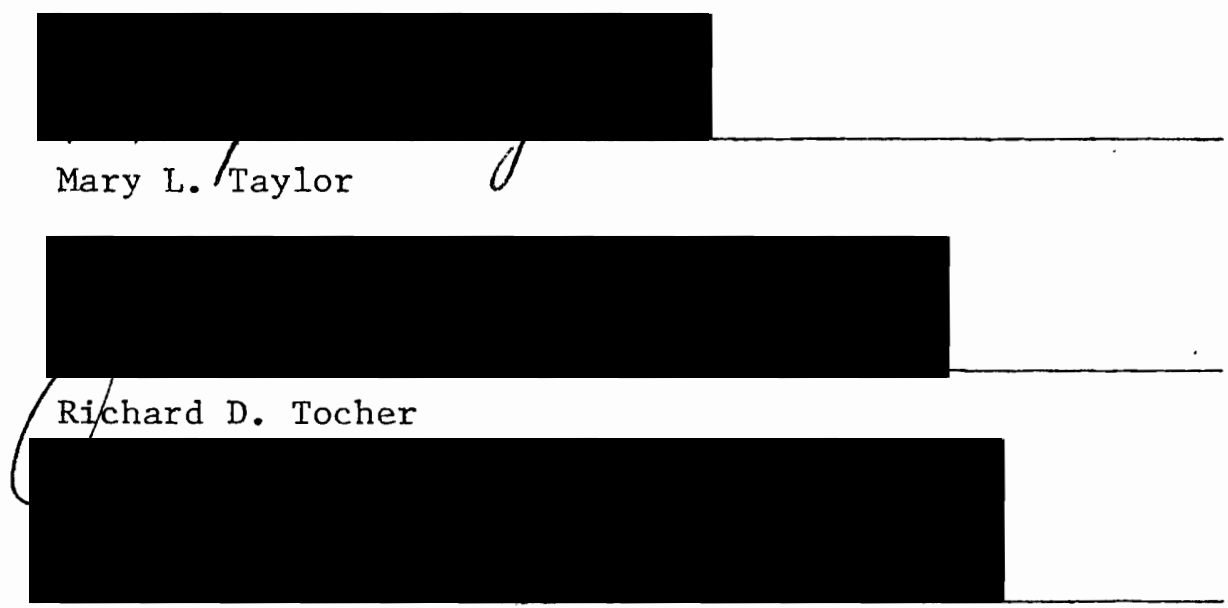

Marc R. Feldesman

Methods were devised for the isolation and pure culture in defined mineral medium of Closterium ehrenbergii Menegh.

(Chlorophyceae). The effect of $\mathrm{pH}$, type of nitrogen source, nitrate concentration, total hardness, and various buffers on growth were investigated. Best growth rates were obtained at $\mathrm{pH} 8$ to.9, but good growth was observed even at $\mathrm{pH}$ 9.4. Nitrate, ammonia, or urea nitrogen could be utilized, but at concentrations greater than $10^{-2} \mathrm{M}$ urea was toxic to growth. At higher concentrations of ammonia and 
nitrate longer lag phases of growth were obtained but eventual higher cell yields were obtained. Good growth rates were obtained with Tris(hydroxymethy1)-aminomethane buffer at up to $10^{-2} \mathrm{M}$; higher concentrations were inhibitory.

Assimilation of nitrate occurred both under light and dark conditions, however the assimilation was slower in the dark. After four days in nitrate-depleted medium, assimilation of nitrate occurred immediately after nitrate was added. This indicated relative stability of the assimilation enzymes. Attempts to determine the $\mathrm{K}_{\mathrm{m}}$ for nitrate uptake yielded results that did not fit the classic Michaelis-Menton hyperbola but may be instead described by sigmoidal kinetics. Daily fluctuations in nitrogen per cell occurred due to synchronous cell division. Attempts to produce a sexual response in defined mineral medium with a known homothallic strain failed. A review of cultural. and observational studies of desmid physiology is included. 


\title{
CULTURE AND GROWTH OF \\ CLOSTERTUM EHRENBERGII (Desmidiaceae)
}

\author{
by \\ DAVID BRUCE RENSTROM
}

A thesis submitted in partial fulfillment of the requirements for the degree of

\author{
MASTER OF SCIENCE \\ in \\ BIOLOGY
}

Portland State University

1979 
TO THE OFFICE OF GRADUATE STUDIES AND RESEARCH:

The members of the Committee approve the thesis of

David Bruce Renstrom presented July 23, 1979.
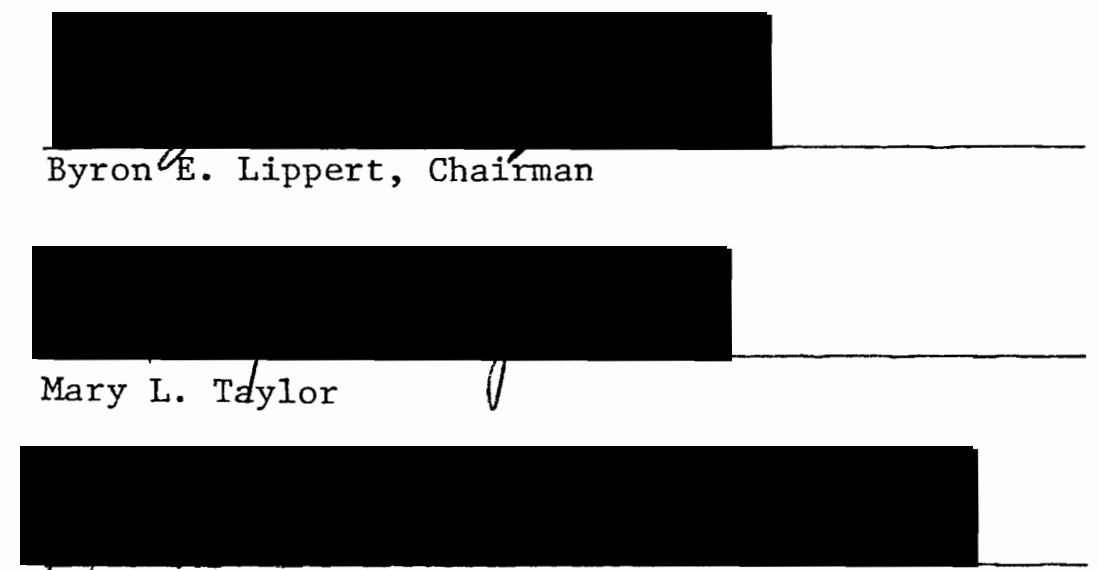

Rifchard D. Tocher

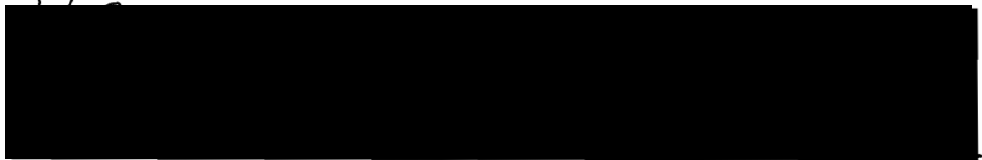

Marc R. Feldesman

APPROVED :

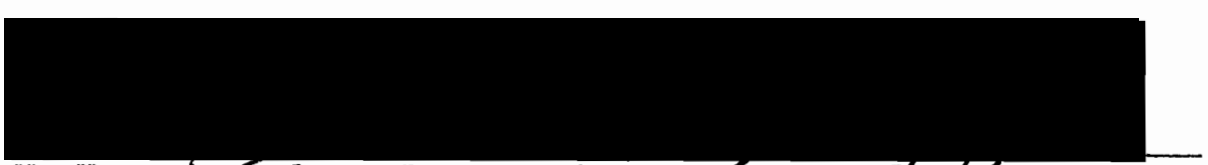

W. Hermantaylor, Jr., Head, Depaftment of Bilology

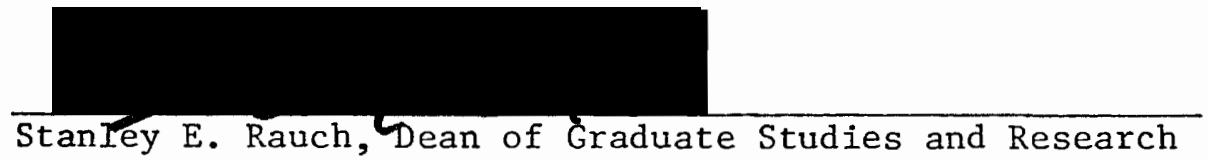




\section{ACKNOWLEDGEMENTS}

I would like to extend my appreciation to my major advisor, Dr. B.E. (Ed) Lippert, for his advice, suggestions, and discussions during this project. I would also like to thank the other members of my committee, Dr. Marc Feldesman, Dr. Mary Taylor, and Dr. Richard Tocher, for their advice, suggestions, and the use of equipment and supplies. I would also like to thank the many other faculty and students at Portland State University who helped me in various ways. Special thanks go to Julia Henry for her moral support and for her help in the preparation and typing of this manuscript. 
TABLE OF CONTENTS

PAGE

ACKNOWLEDGEMENTS . . . . . . . . . . . . . . . . . iii

LIST OF TABLES . . . . . . . . . . . . . . . . . vi vi v

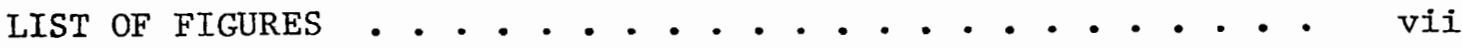

INTRODUCTION ...................... . . . . . 1

MATERIALS AND METHODS . . . . . ........... 11

Growth Measurements • . . . . . . . • . • 13

$\mathrm{pH}$ Experiments . . . . . . . . . . . . . . 15

Buffer Experiments . . . . . . . . . . . 15

Hardness Experiment • • • • • • • • • • • • 17

Nitrate Concentration Variation Experiment • . • • • 17

Nitrate Uptake Experiments • . • • • • • • • • • 17

Uptake Kinetics . • • • • • • • • • • • • • • 19

RESULTS • • • • • • . . • . . . . . . . . . 20

$\mathrm{pH}$ Experiments . • . • . . . . . . . . . . . 20

Buffer Experiments ... . . . . . . . . . . . 20

Hardness Experiment . . . . . . . . . . . . 23

Nitrate Concentration Variation Experiment . . . . . . 23

Nitrate Uptake Experiments . . . . . . . . . . 25

Nitrate Uptake Experiment 非 with Strain \#3 . . . . 25

Synchrony . . . . . . . . . . . . . . . 28

Uptake Kinetics . . . . . . . . . . . . . . 30 
PAGE

CONCLUSIONS • . . . . . . . . . . . . . . . . . . 33

REFERENCES CITEB • . . . . . . . . . . . . . . . . 36

APPENDIX . . . . . . . . . . . . . . . . . . . . 4 40 


\section{LIST OF TABLES}

TABLE

PAGE

I Preparation of Medium A . . . . . . . . 12

II Preparation of Medium A-1 . . . . . . . . 16

III Cell yield of Closterim ehrenbergii \#9 with

Tris-(hydroxymethy1)-aminomethane buffer . . 22

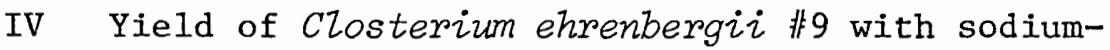
carbonate buffer . . . . . . . 22 


\section{LIST OF FIGURES}

FIGURE

PAGE

1. The effect of initial $\mathrm{pH}$ on yield of Closterium ehrenbergii (\#9) . . . . . . . . . . . .

2. The effect of medium concentration on growth of Closterium ehrenbergii (非) . . . . . . . .

3. The effect of nitrate concentration on growth of Closterium ehrenbergii (非) . . . . . . . . . 26

4. Nitrogen/cell in synchronous cultures of CZosterim ehrenbergii (非3) . . . . . . . . . . . . 27

5. Synchronous cell division of Closterium ehrenbergii (非15) 29

6. Nitrate uptake by Closterium ehrenbergii (非15) . . . . . 31 


\section{INTRODUCTION}

The Zygnematales (or Conjugales) are an order of three families of green algae distinguished by their unique sexual conjugation. Pores in the cell wall are absent in the filamentous Zygnemataceae, including the common genera Spirogyra and Zygnema, and the Mesotaeniaceae (or saccoderm desmids) while such pores (I) and a median constriction between the two semi-cells usually are present in the Desmidiaceae (placoderm or "true" desmids). Thorough discussions of the morphology and taxonomy of the saccoderm and placoderm desmids of North America háve appeared recently $(2,3,4)$.

In the sexual conjugation process, potential gametes align themselves and form a conjugation tube or a loose mucilagenous matrix through which the protoplasts migrate and fuse to form a zygospore. In the zygospore nuclear fusion eventually occurs, but this usually occurs just prior to germination after a period of dormancy (5). The diploid zygospore is generally the only spore formed by the desmids but aplanospores and other haploid spores have been reported $(6,7,8)$. The zygospore is the typical resistant stage in the life cycle, and can withstand periods of dessication. In habitats subject to dessication, sexuality would be assumed to be a well-preserved trait. It has been noted that planktonic desmids of large lakes rarely, if ever, form zygospores (9). In these habitats the desmids probably reproduce only by cell division. In contrast, zygospores of sexual strains are commonly collected in mud samples from seasonal waters (10). 
Sexual strains of desmids make suitable models for the study of physical and chemical factors which may trigger sexuality. The loss of sexuality in algae during prolonged culture: has been a difficulty experienced by many workers (11). This loss of sexuality during laboratory culture is found with algae in general. It is possible that changes in physiological properties occurring during laboratory culture may be a common problem (11). The possibility that the inadvertent selection of mutant genomes adapted to the culture method used has been suggested as a reason for the loss of sexuality (12).

Factors that have been indicated as affecting the sexual response of desmids and other algae in laboratory cultures are (a) light, (b) temperature, (c)the composition of the medium, and (d) carbon dioxide $(10,13,14)$

Starr (10) developed a method to induce conjugation in which log phase cells are suspended in nutrient depleted medium in a watch glass or spot plate and incubated in a petri dish. He found that atmospheric diffusion of carbon dioxide into the medium might be important: a watch glass with its larger surface area produced a higher percentage of conjugating cells and conjugation seemed to occur more readily near the surface of the medium. Increasing the carbon dioxide concentration of the atmosphere by placing a $5 \%$ sodium bicarbonate solution in the petri dish bottom increased the percentage of conjugants. It was also found that removal of carbon dioxide with a $5 \%$ sodium hydroxide solution in the petri dish bottom prevented conjugation. Best results were obtained at a light intensity of about 5500 lux with a daily light cycle of at least 16 hours. Reduction of the light intensity, 
duration of the light cycle, or decreasing the incubation temperature to below $20^{\circ} \mathrm{C}$ decreased or halted conjugation. Lippert $(13,14)$ reported similar results with Closterium ehrenbergii and Closterium moniliferm. The effects of carbon dioxide and light intensity are generally assumed to be due to enhanced photosynthesis (15). However, the possible reduction of $\mathrm{pH}$ in cultures incubated in the presence of increased $\mathrm{CO}_{2}$ may favor zygospore production independently (14). With Closterizm ehrenbergii, $5 \% \mathrm{CO}_{2}$ treatment enhanced zygospore production regardless of $\mathrm{pH}$ but the effect was greater at $\mathrm{pH} 6.2$ than at $\mathrm{pH} 8.8$ (14). Dubois-Tylski (16) reported that light duration, intensity, and quality were all important in sexual induction with desmids.

The use of fresh, rather than nutrient depleted medium, results in a period of cell division prior to conjugation (10). This "depleted medium factor" is probably the nitrogen source(s) in the soil-water medium used by Starr (10), since nitrogen-free medium has been commonly used to induce conjugation in desmids $(12,13,14)$. However, Hoshaw (17) induced sexuality within 5 to 7 days after transfer to fresh medium by increasing the temperature to $26{ }^{\circ} \mathrm{C}$ from $22{ }^{\circ} \mathrm{C}$. Starr (10) suggests that the factors which appear to be operating in laboratory experiments may be important in those natural situations where zygospores are generally found, i.e. temporary waters.

Preliminary experiments (14) indicated enhancement of zygospore formation at 0.02 to $2.0 \mathrm{mg} / 1$ kinetin but complete inhibition at 5.0 to $10.0 \mathrm{mg} / 1$ kinetin. Indole-3-acetic acid (IAA) and naphthaleneacetic acid (NAA) did not seem to have any effect but were possibly inhibitory at $1.0 \mathrm{mg} / 1$ IAA or NAA. Difficulties in reproducibility of 
of experiments (Lippert, personal communication) may be related to the difficulty in controlling other pertinent factors such as nitrogen in soil-water medium.

Starr (10) and Lippert (13, 14) used Pringsheim's soil-water medium (18) with calcium carbonate added to grow those species preferring an alkaline medium. The medium "contains nitrates, ammonia, vitamins, an array of bacterial metabolites, and trace metals chelated by humic acids" (14, p. 742). The fact that some algae could be grown only on this undefined medium was one of the clues which led to the search for the then unknown factors, such as vitamins, which were required by these algae. Many algae have since been shown to require one or more of the vitamins-thiamine, biotin, or $\mathrm{B}_{12}$ (cyanocobalamine). On1y $B_{12}$ has been shown to be required by any of the desmids $(11,19$, 20). Axenic (pure) cultures of Clostemium strigosum initially required vitamin $B_{12}$. After extended culture in mineral medium plus soil extract this organism did not require it any longer (20). As previously noted, such changes in synthetic ability may be a common problem with laboratory cultures (11).

The culture of algae in mineral media dates back to the $1890^{\prime}$, when Beijerinck, Molisch, and Miguel succeeded in culturing a number of green algae and diatoms (11). Their success with these autotrophic organisms obscured the fact that up to $70 \%$ of algal species have now been shown to require one or more growth factors and consequently would not grow in their strictly mineral media (11). Pure cultures of desmids were probably first obtained in 1926 by Czurda (21), a student of Pringsheim. 
The use of axenic cultures may be a theoretical, rather than a practical, necessity for the determination of many physiological characteristics when using mineral media. Several desmid researchers $(19,20)$ have considered the results of unialgal cultures in mineral medium to be equally valid to those in axenic culture. Extracellular polysaccharide production by algae is usually minimal during exponential growth (22). This is possibly due to the slow rate of autolysis compared to lag and stationary growth phases. Experimental results, using exponentially growing cultures are probably not affected by bacterial interferences. Moss (19) accepts growth measurements obtained with vitamin utilization in non-axenic cultures partly because even with bacteria present the alga required the addition of vitamins.

Culture research with desmids has often paralleled field research which attempts to describe the physical and chemical determinants of desmid distribution in natural waters. Field data frequently led to the hypothesis that desmids were calciphobic and favored by a high ratio of monovalent to divalent cations. However, Moss (23) compared the effect of calcium concentration and the ratio of monovalent to divalent cations on a number of desmid and other algal species that are characteristic of soft and hard waters. He concluded that these factors probably are unimportant in determining the distribution of soft water (oligotrophic) and hard water (eutrophic) species. These terms are used in the original sense in this paper, i.e. based on hardness, rather than in accord with more recent usage equating eutrophy to high productivity and oligotrophy to low productivity (24). 
This new usage ties the terms to nutrient availability, which may not be apparent from levels of dissolved nutrients.

Moss (23) also reported different minimum calcium requirements for algae. Some oligotrophic, filamentous desmids had the highest minimum requirements ( 1 to $3 \mathrm{mg} / 1 \mathrm{Ca}$ ). Calcium concentrations of this order are unlikely to be limiting in any natural waters. Growth of desmids endemic to soft waters (less than $90 \mathrm{mg} / 1$ hardness as $\mathrm{CaCO}_{3}$ ) was not affected by levels of calcium up to $100 \mathrm{mg} / \mathrm{l}$ or by the ratio of monovalent to divalent cations. Algae of harder waters (up to 360 $\mathrm{mg} / 1$ hardness as $\left.\mathrm{CaCO}_{3}\right)$ were unaffected by low $(1 \mathrm{mg} / \mathrm{l})$ or high (100 mg/1) calcium. Tassigny (20) reported that cultures of Staurastrom sebaldi Reinch var. omatzon Nordst., Closterizon strigosum Ehr. and Micrasterias crux-melitensis (Ehr.) Hassal. had a 20 to $30 \%$ increase in generation times at increased calcium ion concentration. Staurastrom paradoxum Meyen, common in eutrophic waters, was indifferent to calcium ion concentration. These results are criticized by Fioss (23) on the basis that unnaturally high ionic concentrations were used in the media. Gough (25) examined the growth of Closterizm moniliferm and Cosmarizm granatum from hard waters and Triploceras gracile from an acid bog at high $(50 \mathrm{mg} / 1)$ and low $(3 \mathrm{mg} / 1)$ calcium ion concentration. Each calcium concentration was tested at high (8.5) and low $(6.0) \mathrm{pH}$. Low $\mathrm{pH}$ and low calcium concentration favored the growth of Triploceras but high $\mathrm{pH}$ at either calcium concentration favored closterium. He contended that both high $\mathrm{pH}$ and high calcium concentration favored the growth of $C$. granatron, but his interpretation was based on relatively small differences in growth rate at the two calcium 
concentrations.

The presence of a diverse desmid flora (more than 20 species) is considered indicative of oligotrophy (23) when oligotrophy is used in the original sense of soft waters. Hardness is commonly measured as alkalinity (weak acid salt concentration) and expressed as bicarbonate $\left(\mathrm{HCO}_{3}^{-}\right)$or as $\mathrm{CaCO}_{3}$ since these commonly make the greatest contribution. Conductivity may be roughly converted to alkalinity by the relation $125 \mu \mathrm{mho} / \mathrm{ml}=1 \mathrm{~m}$-equiv. $\mathrm{HCO}_{3}^{-}$(23). Moss (23) uses a citation from Rodhe to estimate the concentration of the other major ions which may be expected to occur with a given bicarbonate concentration in natural waters.

Highly productive, often nutrient enriched, soft waters may retain much of their "oligotrophic" algal flora but unproductive hard waters have similar flora to that of productive hard waters (23). The use of algal species as indicators of trophic status is critically reviewed by Brook (26), who apparently defines eutrophy/oligotrophy in terms of productivity. Tassigny (27) presents considerable field data on the use of algae, particularly desmid species, as trophic indicators. Much of the confusion associated with the use of trophic status terminology seems to be due to the failure of some authors to adequately define their use of the terms, or even to attach different meanings in different context.

Moss (28) examined the growth of 25 marker species and found, relative to the carbon dioxide-bicarbonate-pH system, no differences in the minimum $\mathrm{pH}$ tolerated by eutrophic versus oligotrophic species. However, eutrophic species usually tolerated a higher maximum $\mathrm{pH}(>9.3)$ 
than oligotrophic species $(<8,6)$. Experimental evidence is presented to exclude ionic content and trace metal availability as explanations for his results. The simplest and perhaps most reasonable explanation is the availability of free carbon dioxide for photosynthesis. As the $\mathrm{pH}$ increased above 7.7 , free $\mathrm{CO}_{2}$ in the medium decreases to a minimum, and growth rates of the oligotrophic organisms decreased correspondingly. The continued growth of some algal species at higher $\mathrm{pH}$ is probably due to active absorption of bicarbonate, which is converted to carbon dioxide by the activity of the enzyme carbonic anhydrase. A rigorous proof for the utilization of bicarbonate may be impossible (29) since some free $\mathrm{CO}_{2}$ is always present in solution at any $\mathrm{pH}$. It should be noted that those desmids with a typically wider distribution, such as certain species of Staurastrum, Cosmarium, and Closterium, had a much wider distribution in waters of varying types than did other desmid genera. The vascular plant Utricularia, supported the widest diversity of desmids wherever it occurred. "High generic diversity. was correlated with low conductivity, calcium, and alkalinity, $\mathrm{pH}$ of 5.1 to 7.0 and the presence of free carbon dioxide" (32).

Division rates in exponentially growing desmid cultures are slow compared to other algae ( 0.1 to 1.0 divisions/day). Direct comparisons of yield are difficult to obtain and are seldom reported. Using cell organic content as a measure of size, Moss (19) demonstrated little correlation between size and growth rate. The expected (by this author) correlation may only occur at optimal growth rates. Moss also investigated the relationship between growth rate and temperature (19). The broad range of optimal temperatures in his results may be 
due to culture conditions in which temperature is not clearly the limiting factor; two other potentially limiting variables, i.e., light and turbulence, were not investigated. More rigorous experiments with light and temperature limited growth of Chlorella (34) showed that "temperature has little effect on photosynthesis and growth in lightlimited systems" (34, p. 723). With these synchronous cultures of ChZorelza under temperature-limited conditions, an exponential increase in yield occurred from 20 to $30^{\circ} \mathrm{C}$ with a $Q_{10}$ of about 6 . It would appear that growth must be optimized before the effect of temperature and perhaps other variables on growth can be accurately investigated. The effect of cell division synchrony on growth rate determinations may be a special problem with desmids. Division occurs predominantly or exclusively at night with most species of desmids $(35,36)$, so that a degree of cell division synchrony is always present in growing desmid cultures. Schulle (37) reports synchronous division of Staurastrum pingue Teil. at a definite time after the beginning of the light period. His claims for the first synchronous desmid cultures are, however, unjustified (see 35,36 ).

Many species of algae have been shown to be able to use a wide variety of nitrogen sources, including nitrate, ammonia, urea, various amino acids and other organic nitrogenous compounds. Moss (19) investigated growth of desmids with nitrate or ammonia as a nitrogen source and obtained similar growth rates with either.

My work with Closterium ehrenbergii was primarily intended to develop efficient and reliable techniques for axenically culturing the organism in mineral medium. Axenic cultures contain no organisms 
other than the desired species and are synonymous with pure cultures. The use of pure cultures for physiological experiments precludes the possibility of interferences which may arise from the presence of contaminant microorganisms. Mineral media may be defined, i.e. the concentrations of all components are known. This is necessary for most physiological experimentation, especially where growth requirements are being investigated. The lack of carbon sources in mineral medium is an added benefit in that the growth of contaminant bacteria and fungi is inhibited by the lack of carbon sources other than the extracellular products of the research organism.

After good growth. of pure Closterium ehrenbergii in defined mineral medium was obtained, a series of growth experiments were conducted to investigate the effects of (a) total salt concentration, (b) $\mathrm{pH}$, (c) various buffers at varied $\mathrm{pH}$, (d) nitrogen source, and (e) nitrate concentration. The effects of $\mathrm{pH}$ and nitrogen on growth were investigated because they have been indicated to be important to the sexual response of desmids. Further experiments were conducted with the uptake of nitrate as exclusive nitrogen source. 


\section{MATERIALS AND METHODS}

closterium ehrenbergii Menegh. (Desmidiaceae, Chlorophyceae) was found in abundance on the surface of submerged decaying alder (AInus mbra) leaves in very shallow spring-fed seepage ponds near Oaks Park, Portland, Oregon in March 1976. A number of collections from discrete masses of nearly unialgal cells were made and 12 unialgal clones were successfully grown from single cells isolated by capillary pipette into soil-water medium with added $\mathrm{CaCO}_{3}$ (18).

Using the method of Starr (39), I found that one clone was homothallic, 4 were one member of a heterothallic pair (t strain) and 7 were the other member (- strain). Visually observed differences in $\therefore$ growth on soil-water medium may indicate that the various plus ( + ) or minus (-) strains are not necessarily physiological equivalents but for the purposes of further study, the homothallic strain (非) and one each of the plus (非9) and the minus (非15) were ișolated axenically by manipulation with a glass microneedle on agar medium so as to remove accompanying microorganisms (40). Initially axenic (pure) cultures were established in soil-water medium preconditioned by growth of unialgal Closterium. The growth medium was filter sterilized with a $0.22 \mu$ millipore filter $(0.45 \mu$ filters selectively passed one strain of bacteria). Later a mineral medium [medium A (Table I)] was devised which supported good growth and axenic cultures were established directly on medium A agar ( $1 \%$ Difco) by micro-manipulation and transferred to liquid medium $A$ or its later modifications. Vigorously 
TABLE I

PREPARATION OF MEDIUM A

Medium

Concentration (mg/1) Molarity

Major ions $^{a}$

$\begin{array}{lll}\mathrm{NaNO}_{3} & 62.5 & 7.25 \times 10^{-4} \\ \mathrm{MgSO}_{4} \cdot 7 \mathrm{H}_{2} \mathrm{O} & 18.7 & 5.10 \times 10^{-5} \\ \mathrm{CaCl}_{2} \cdot 2 \mathrm{H}_{2} \mathrm{O} & 25.0 & 1.7 \times 10^{-4} \\ \left(\mathrm{NH}_{4}\right)_{2}{ }^{\mathrm{HPO}}{ }_{4} & 20.0 & 1.5 \times 10^{-4}\end{array}$

Bold's minor element ${ }^{a}$

solutions (44)

1. $\mathrm{Na}_{2}$ EDTA

$\mathrm{KOH}$

2. $\mathrm{FeSO}_{4} \cdot 7 \mathrm{H}_{2} \mathrm{O}$

3. $\mathrm{H}_{3} \mathrm{BO}_{3}$

4. $\mathrm{ZnSO}_{4} \cdot 7 \mathrm{H}_{2} \mathrm{O}$

$\mathrm{MnCl}_{2} \cdot 4 \mathrm{H}_{2} \mathrm{O}$

$\mathrm{MoO}_{3}$

$\mathrm{CuSO}_{4} \cdot 5 \mathrm{H}_{2} \mathrm{O}$

$\mathrm{Co}\left(\mathrm{NO}_{3}\right) \cdot 6 \mathrm{H}_{2} \mathrm{O}$

Vitamin solution ${ }^{b}$

thiamine $-\mathrm{HCl}$

biotin

$\mathrm{B}_{12}$
50.0

31.0

5.0 acidified with $1 \mathrm{ml} / 1 \mathrm{H}_{2} \mathrm{SO}_{4}$

11.4

8.82

1.44

0.85

1.57

0.49

${ }^{a}$ AR grade chemicals were used for media preparation.

${ }^{\mathrm{b}} \mathrm{A}$ combined vitamin solution was prepared. $12 \%$ water hydration was allowed when weighing $\mathrm{B}_{12}$ and $4 \%$ for biotin (42). This vitamin solution was acidified to $\mathrm{pH} 5$ with concentrated $\mathrm{HCl}$ and autoclaved separately from the medium. One $\mathrm{ml} / 1$ was added after cooling to give the required medium concentration. 
growing cells are used much more successfully to establish pure cultures.

Axenic condition was tested for in cultures used for innoculation and at the conclusion of experiments. Cultures were plated on nutrient agar (Difco) plus $3 \mathrm{~g} / 1$ yeast extract and on medium $\mathrm{A}$ agar. Plates of each medium were incubáted at $25^{\circ} \mathrm{C}$ and at room temperature for up to 2 weeks. Occasionally, platings were made on a variety of other bacterial media. Microscopic examination of cultures with the oil immersion objective of a compound microscope failed to indicate the presence of bacteria if they were not also indicated by the plating.

Axenic cultures were routinely grown in a culture room at $20{ }^{\circ} \mathrm{C}$ $\pm 1{ }^{\circ} \mathrm{C}$ on a $16 / 8$ hour Iight/dark cycle. Light (approximately 3300 lux at the surface of experimental culture vessels) was provided by cool. white fluorescent fixtures. For maintenance of cultures, the cultures were exposed to 3300 lux until good growth was evident and then were stored at much lower light levels (approximately 550 lux).

All glassware used as culture chambers or in the preparation of media was cleaned by soaking in a solution of concentrated nitric acid and sulfuric acid (40/60) for at least 24 hours. Each piece was then rinsed in 25 volumes of glass distilled water. Glass distilled water was used for all media and reagent preparation.

\section{GROWTH MEASUREMENTS}

Change in cell number was used as a measure of growth; measurements of optical density (turbidity) did not give the necessary precision in these dilute cultures and dry weight measurements 
required too large a culture volume. Cell number was determined by a minimum of 3 counts of $1 \mathrm{ml}$ aliquots from the culture vesse1. Since sample size was small (10-500 cells/ml), the entire aliquot was counted. Cells were dispersed within the growth chamber by swirling the flask or tube until cells no longer adhered to the walls of the vessel. It was interesting to note that cells adsorbed to the glassware more during early stages of growth and ceased to adsorb as cells approached stationary phase. The percent standard deviation of replicate counts seldom exceeded $10 \%$, and the methods for dispersion within the growth chamber and sampling error were deemed acceptable.

In graphical presentations of results, mean cell numbers \pm one standard deviation are presented. Numerically, this gives very similar results to precision at the $95 \%$ confidence level.

The following expression describes growth rate (41):

$$
k=\frac{\log _{2}\left(N_{1} / N_{0}\right)}{t_{1}-t_{0}}
$$

where $\mathrm{N}_{0}$ = initial cell number at $t_{0}, \mathrm{~N}_{1}=\operatorname{cell}$ number at $t_{1}, t_{1}$ and $t_{0}=$ days, and $k=$ specific growth rate constant in divisions/day .

A degree of synchronous cell division is always apparent in growing cultures of $C$. ehrenbergii, since cell division occurs almost exclusively during the last four hours of the dark period. The degree of synchronous cell division is considered to be the percentage of cells dividing during a given dark period. Enhanced synchronous cell division is that which occurs above the normal (or average) percentage of cell division during exponential growth. 
PH EXPERIMENTS

The effect of $\mathrm{pH}$ on growth of strain 非 was investigated in unbuffered medium $\mathrm{A}$. The initial $\mathrm{pH}$ was adjusted with $\mathrm{HCl}$ or $\mathrm{NaOH}$ at increments of one $\mathrm{pH}$ unit over the range of $\mathrm{pH} 4$ to 10 . The $\mathrm{pH}$ of the unadjusted medium was 9.0. No attempt was made to control the $\mathrm{pH}$ during the course of the experiment. Yields of strain $\# 9$ were determined by cell counts at stationary phase. Three replicate cultures in $18 \times 150 \mathrm{~mm}$ test tubes with $10 \mathrm{ml}$ of medium were used at each $\mathrm{pH}$. Culture conditions were as previously stated.

\section{BUFFER EXPERIMENTS}

In order to determine if buffer and buffer concentration affect the final yield, the cell number of strain \#9 was determined when cells reached stationary phase after growth in medium A-1 with Tris-(hydroxymethyl)-aminomethane buffer (Tris) at $10^{-1}, 10^{-2}$, and $10^{-3}$ molar. Each concentration was tested at $\mathrm{pH} 7.8,8.3$, and 8.8. A similar experiment with sodium-carbonate buffer (at the same concentrations as the Tris buffer) and $\mathrm{pH}$ of 9.3, 9.8, and 10.3 was also used. The $\mathrm{pH}$ during the course of the experiments was not controlled. Three replicate cultures in $18 \times 150 \mathrm{ml}$ test tubes with $10 \mathrm{ml}$ of medium were used at each $\mathrm{pH}$ and buffer concentration. Small innocula (about 15 cells $/ \mathrm{ml}$ ) were used. Culture conditions were as previously stated. 
TABLE II

PREPARATION OF MEDIUM $A-1^{a}$

Medium

Concentration (mg/1) Molarity

Major ions

$\begin{array}{lcc}\mathrm{NaH}_{2} \mathrm{PO}_{4} & 6.9 & 5.0 \times 10^{-5} \\ \mathrm{KH}_{2} \mathrm{PO}_{4} & 6.8 & 5.0 \times 10^{-5} \\ \mathrm{KNO}_{3} & \text { Variable } & \text { \} up to } 212 \mu \mathrm{M} \\ \mathrm{NaNO}_{3} & \text { Variable } & \end{array}$

Buffer $^{c}$

Tris-(hydroxymethy1)-aminomethane

$5.0 \times 10^{-3}$

apreparation is as for medium A except for the following differences: $\left(\mathrm{NH}_{4}\right)_{2} \mathrm{HPO}_{4}$ is omitted and the above listed major ions are added.

$\mathrm{b}_{\mathrm{KNO}_{3}}$ and $\mathrm{NaNO}_{3}$ were varied at a constant ratio.

Medium A-1 was titrated to $\mathrm{pH} 8.2$ with HCl. A Sargent-Welch

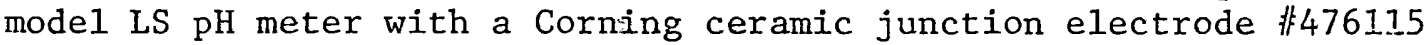
suitable for use with Tris (46) was used for all experiments using Tris buffered medium. Tris standards at $\mathrm{pH} 7.2$ and 9.0 were prepared from dessicated Tris base and Tris HC1 (46). 


\section{HARDNESS EXPERIMENT}

Strain $\# 3$ was grown in medium $A$ at $\frac{1}{4}, \frac{1}{2}$, normal, twice normal, and four times normal total salt concentration (hardness), measured as $\mathrm{mg} / 1$ added reagents. Total salt concentration varied from $41 \mathrm{mg} / 1$ to $656 \mathrm{mg} / 1$. Cell yield (cells/ml) and growth rates were determined. Two replicate cultures in test tubes with stainless steel closures were counted at various stages of growth until stationary phase was reached. Culture conditions were as previously stated.

\section{NITRATE CONCENTRATION VARIATION EXPERIMENT}

Strain 非 9 was grown in medium A-1 (Table II) containing $6.6 \mu \mathrm{M}$, $53 \mu \mathrm{M}$, or $212 \mu \mathrm{M}$ nitrate. Cultures in $250 \mathrm{ml}$ cotton-stoppered Er.1 e nmeyer flasks contained $150 \mathrm{ml}$ of medium and were innoculated with $15 \mathrm{cells} / \mathrm{ml}$. Cell counts were made at intervals until stationary phase was reached. Culture conditions were as previously described.

\section{NITRATE UPTAKE EXPERIMENTS}

Strains 非 3 and $\# 15$ were used in these experiments. Cultures were in $250 \mathrm{ml}, 500 \mathrm{ml}$, or 1 liter cotton-stoppered Erlenmeyer flasks.

Cultures were aerated with filtered air. Air was first passed through a saturated $\mathrm{ZnCl}_{2}$ solution to remove traces of ammonia and subsequently passed through two successive distilled water baths to insure that there was no $\mathrm{ZnCl}_{2}$ contamination and to saturate the air with water vapor.

Experiments were conducted with exponentially growing cells fully induced for nitrate uptake in medium A-1. Exceptions to this 
were experiments to test the effect of lag phase or synchronous growth. Cultures could be made synchronous above the normal level of approximately $20 \%$ by adding nitrate after several days of nitrate depletion.

Cell number and nitrate concentration of the medium were determined for several days. From this data, nitrogen/cell (cellular quota) and total cellular nitrogen of the culture were calculated, assuming total cellular nitrogen to be equivalent to depletion of nitrate from the medium.

Cultures were axenic at the beginning of experiments and bacterial growth during the course of the experiments was minimal. Nitrate was added during the course of the experiments to prevent its depletion. Large innocula were used so that measurable changes in nitrate concentration occurred within a reasonable time. The innocula were prepared by allowing the cells to settle, decanting the medium, washing the cells with sterile nitrate-free medium, and resuspending the cells in fresh medium.

Nitrate and nitrite concentrations were determined by the copper cadmium reduction method (44). Uptake of nitrate was assumed to be equivalent to the depletion of nitrate from the medium. Ethylenediaminetetraacetic acid (EDTA) used in medium A-1 was found to interfere with the reduction of nitrate to nitrite. Experiments to measure nitrate uptake used medium A-I minus the EDTA and trace metals were reduced to a tenth of the concentrations given in Table I.

Cells were removed from samples for nitrate analysis by filtration through nylon filter floss prior to the nitrate analysis. 
Generally, $25 \mathrm{ml}$ were required for nitrate determinations, although at concentrations higher than $20 \mu \mathrm{M}$, smaller samples were removed and diluted with distilled water to $25 \mathrm{ml}$.

Nitrate standards were prepared in distilled water and treated in the same way as the samples. Standard curves were prepared daily as well as periodically during the experiments. Colorimetric determinations of standards conformed well to Beer's law between 2 and $20 \mu \mathrm{M}$ nitrate. Straight line fits were drawn by eye between at least foux absorbance values for nitrate standards. Nitrite concentrations were also determined colorimetrically in the same way as the nitrate, although the prior reduction step is omitted. Nitrite was not detected in any samples, at a limit of detection of about $0.2 \mu M$ nitrite.

Direct nesslerization, a simple colorimetric method (45), was used to analyse for ammonium, although none was detected in any sample. The level of detection was about $1.2 \mu \mathrm{M}$ ammonium.

Culture conditions were otherwise as previously stated. UPTAKE KINETICS

Nitrate concentration and cellular nitrogen were monitored as a function of time. Cellular nitrogen is again considered equivalent to the depletion of nitrate from the medium. Rate of uptake was calculated as umoles nitrate/umoles cellular nitrogen per hour. Duplicate determinations were made and precision was greater than 0.5 umole. Methods and culture conditions were as mentioned under nitrate uptake. 
RESULTS

\section{pH EXPERTMENTS}

The initial $\mathrm{pH}$ of unbuffered medium $\mathrm{A}$ had a strong effect on the eventual yield of strain $\$$ 9 as shown in Figure 1 . It can be seen that the largest cell number was found at alkaline $\mathrm{pH}$. Large changes in $\mathrm{pH}$ probably occurred because of the very low buffering capacity of medium A, although this was not investigated.

\section{BUFFER EXPERIMENTS}

The yield of strain $\#$, in cells/ml, with three concentrations of Tris buffer at three $\mathrm{pH}$ values is presented in Table III. The yield of strain \#9 with three concentrations of sodium-carbonate buffer and three $\mathrm{pH}$ values is shown in Table IV. The yields at $\mathrm{pH}$ 8.3 and 8.8 with $10^{-2}$ and $10^{-3} \mathrm{M}$ Tris were significantly higher than at $\mathrm{pH} 7.8$ at the $95 \%$ confidence level. The trend indicated that $\mathrm{pH} 8.8$ was preferred, although the difference in yield at $\mathrm{pH} 8.3$ and at 8.8 was not significant at this confidence level.

The results with sodium-carbonate buffer were suspect because in the open system in which these experiments were conducted, equilibration with atmospheric $\mathrm{CO}_{2}$ causes changes in $\mathrm{pH}$. Since Tris appeared more useful, no further experiments with carbonate buffers were conducted.

In all subsequent culture media in which Tris buffer was used, 


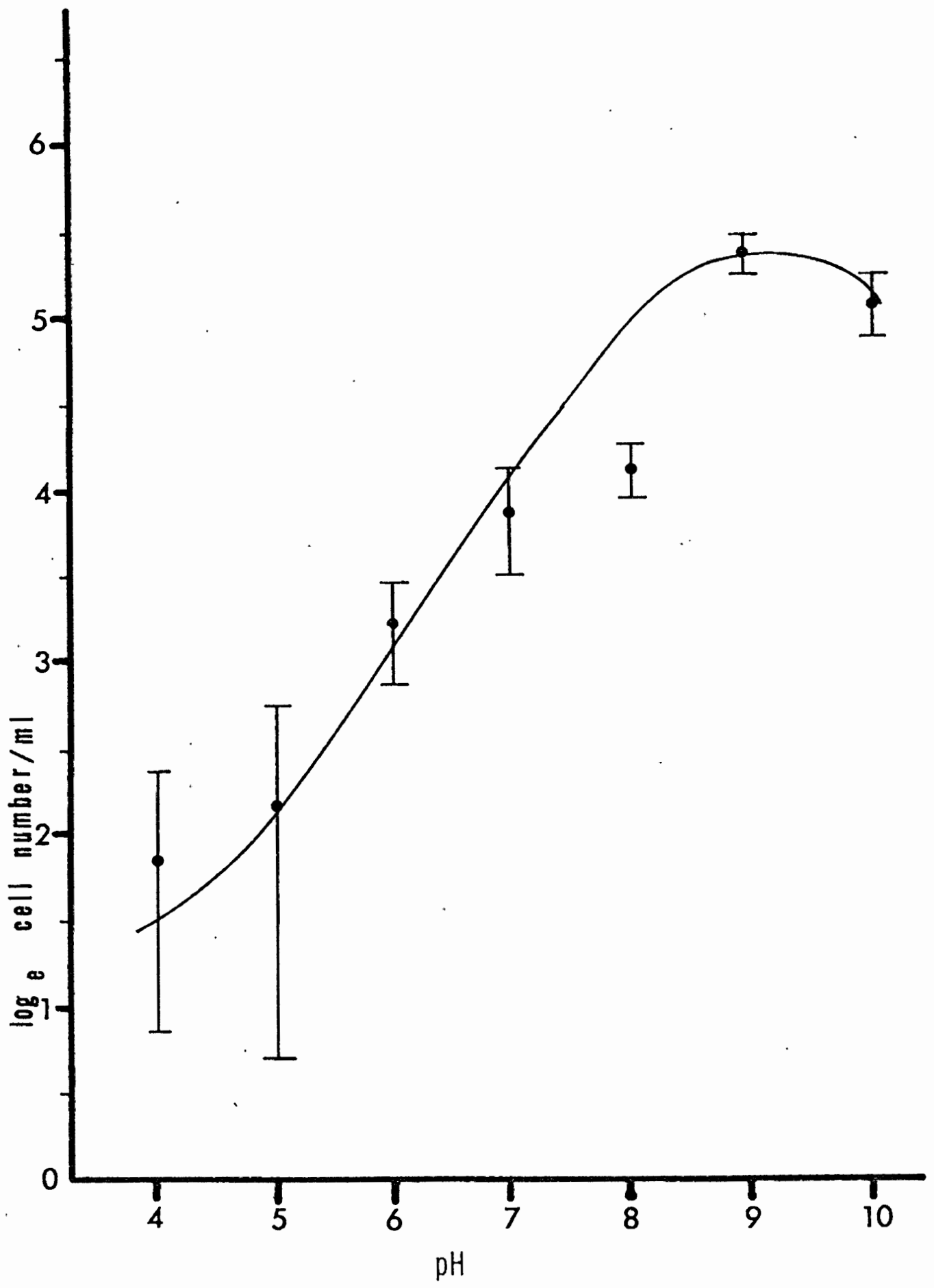

Figure 1. The effect of initial pH on yield of CZosterium ehrenbergii (非).

I indicates the mean \pm one standard deviation 
TABLE III

YIELD OF CLOSTERIUM EHRENBERGII \# 9 a WITH TRIS BUFFER

\begin{tabular}{|c|c|c|c|}
\hline \multirow{2}{*}{$\begin{array}{c}\text { Tris } \\
\text { Concentration }\end{array}$} & \multicolumn{3}{|c|}{$\mathrm{pH}$} \\
\cline { 2 - 4 } & 7.8 & \multicolumn{2}{|c|}{8.3} \\
$10^{-3} \mathrm{M}$ & $413 \pm 41$ & $640 \pm 30$ & $720 \pm 43$ \\
$10^{-2} \mathrm{M}$ & $441 \pm 30$ & $651 \pm 100$ & $761 \pm 95$ \\
$10^{-1} \mathrm{M}$ & toxic $^{\mathrm{b}}$ & toxic & toxic \\
\hline
\end{tabular}

a. in cells $/ \mathrm{m} 1 \pm$ one standard deviation

b. cell death occurs

TABLE IV

YIELD OF CLOSTERIUM EHRENBERGII 非

WITH SODIUM-CARBONATE BUFFER

\begin{tabular}{|c|c|c|c|}
\hline \multirow{2}{*}{$\begin{array}{l}\text { Na-carbonate } \\
\text { Concentration }\end{array}$} & \multicolumn{3}{|c|}{$\mathrm{pH}$} \\
\hline & 9.3 & 9.8 & 10.3 \\
\hline $\begin{array}{l}10^{-3} \mathrm{M} \\
10^{-2} \mathrm{M} \\
10^{-1} \mathrm{M}\end{array}$ & $\begin{array}{c}395 \pm 38 \\
\text { toxic } \\
\text { toxic }\end{array}$ & $\begin{array}{l}416 \pm 37 \\
\text { toxic } \\
\text { toxic }\end{array}$ & $\begin{array}{c}322 \pm 18 \\
\text { toxic } \\
\text { toxic }\end{array}$ \\
\hline
\end{tabular}


the concentration was $.005 \mathrm{M}$ and the $\mathrm{pH}$ was adjusted to 8.2 with $\mathrm{HCl}$. This $\mathrm{pH}$, which was lower than that which yielded maximal growth, was chosen to increase the buffering capacity of the Tris (pK 8.3). Various measurements of $\mathrm{pH}$ during growth experiments using .005M Tris did not vary more than $\pm 0.30 \mathrm{pH}$ units from the initial $\mathrm{pH}$.

\section{HARDNESS EXPERIMENT}

Growth and yield of strain $\$ 3$ at different total salt concentrations of medium A from $41 \mathrm{mg} / 1$ up to $656 \mathrm{mg} / 1$ indicated that higher concentrations inhibited final yield (see Figure 2). The dynamics of growth rate were not apparent in these batch culture experiments, especially maximum growth rates. A speculation is that yield is limited by the higher salt concentrations. At $41 \mathrm{mg} / 1$ total salts the yield is limited by nitrate, as indicated by later experiments where nitrate alone was varied. However this cannot be the case at the two higher salt concentrations, which have respectively 8 and 16 times the nitrate concentrations as the $41 \mathrm{mg} / 1$ total salt concentration. The similarity in the curves at $41 \mathrm{mg} / 1$ and $328 \mathrm{mg} / 1$ total salts appears to be caused by distinct phenomenon, i.e. nitrate limitation at $41 \mathrm{mg} / 1$ and inhibition by high total salt concentration at 328 and $656 \mathrm{mg} / 1$. The results at 82 and $164 \mathrm{mg} / 1$ were practically identical and are combined in Figure 2 .

\section{NITRATE CONCENTRATION VARIATION EXPERIMENT}

Growth rates of strain $\|_{9}$ were not significantly different at the three nitrate concentrations, with possibly a longer lag phase 


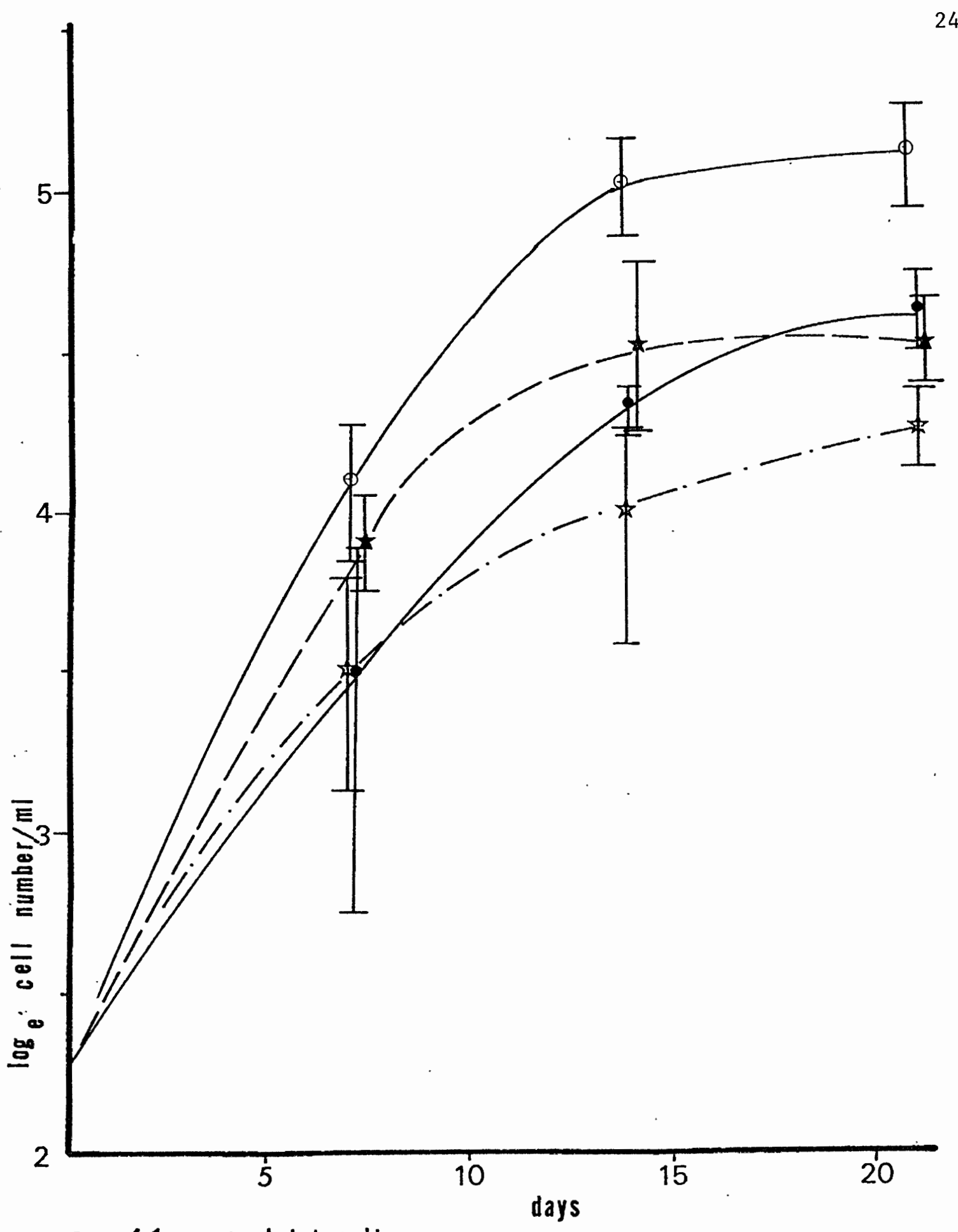

- $41 \mathrm{mg} / \mathrm{l}$ total salts

- 82 " " " and $164 \mathrm{mg} / \mathrm{I}$ combined

$\star 328$ " 656 " "

Figure 2. The effect of medium concentration on growth of Closterium ehrenbergii ( $(3)$. 
occurring at the highest concentration [212 $\mu \mathrm{M}$ (see Figure 3)]. If the yield at these nitrate concentrations is plotted versus the nitrate concentration, a relatively straight line results. This line does not intersect the abscissa at zero yield with zero added nitrate. It seems doubtful that ammonium contamination from the atmosphere or excess nitrogen stored in the innoculum cells could account for this discrepancy.

NITRATE UPTAKE EXPERIMENTS

Specific growth rates $(k)$ in these experiments were higher than in previous work, averaging 0.15 to 0.25 divisions/day, instead of 0.05 to 0.10 division/day. Presumably this was due to the aeration by water saturated, ammonia-free air. This probably indicates that growth rates in previous experiments were carbon-limited. No experiments with aeration at higher concentrations of carbon dioxide were conducted to test for this possibility.

Nitrate:Uptake Experiment '非 1 with Strain \#3

Data obtained from the second and third days of growth (after nitrate depletion for three days) are presented in Figure 4. The large fluctuation in cellular nitrogen quota during the second night shown in Figure 4 is the result of cell division, which occurs almost exclusively at night. When cells reach stationary phase, the cells are nitrogen depleted. When cultures are innoculated with stationary phase cells the apparent cellular quota rises to a maximum within a few days before assuming more regular fluctuations. This may be due to the fact that cell quota values are averages of all 


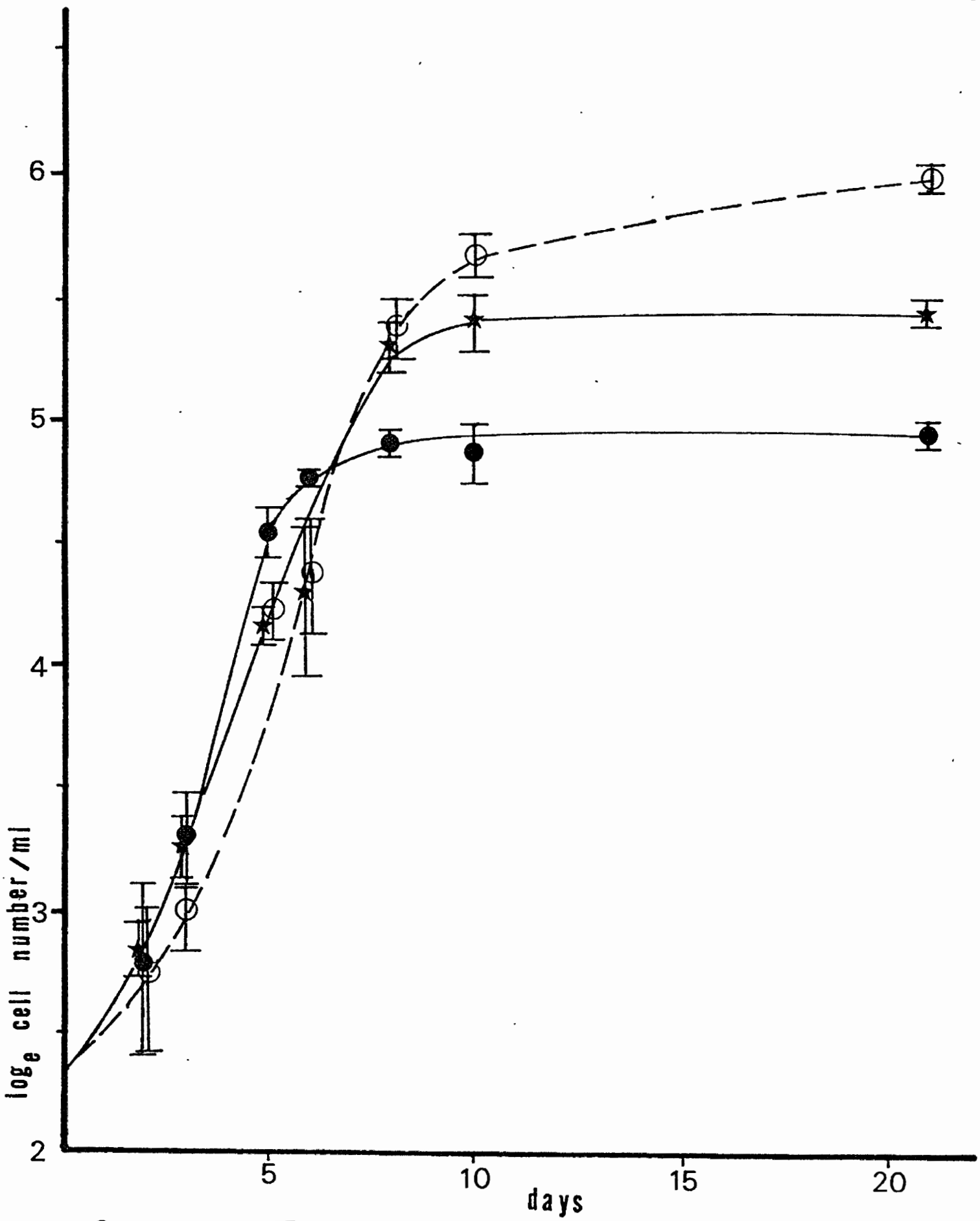

- $6.6 \mu \mathrm{M} \mathrm{N0} \mathrm{N}_{3}^{-}$

$\star 53 "$ "

○ी2" "

Figure 3. The effect of nitrate concentration on growth of Closterium ehrenbergii (非). 


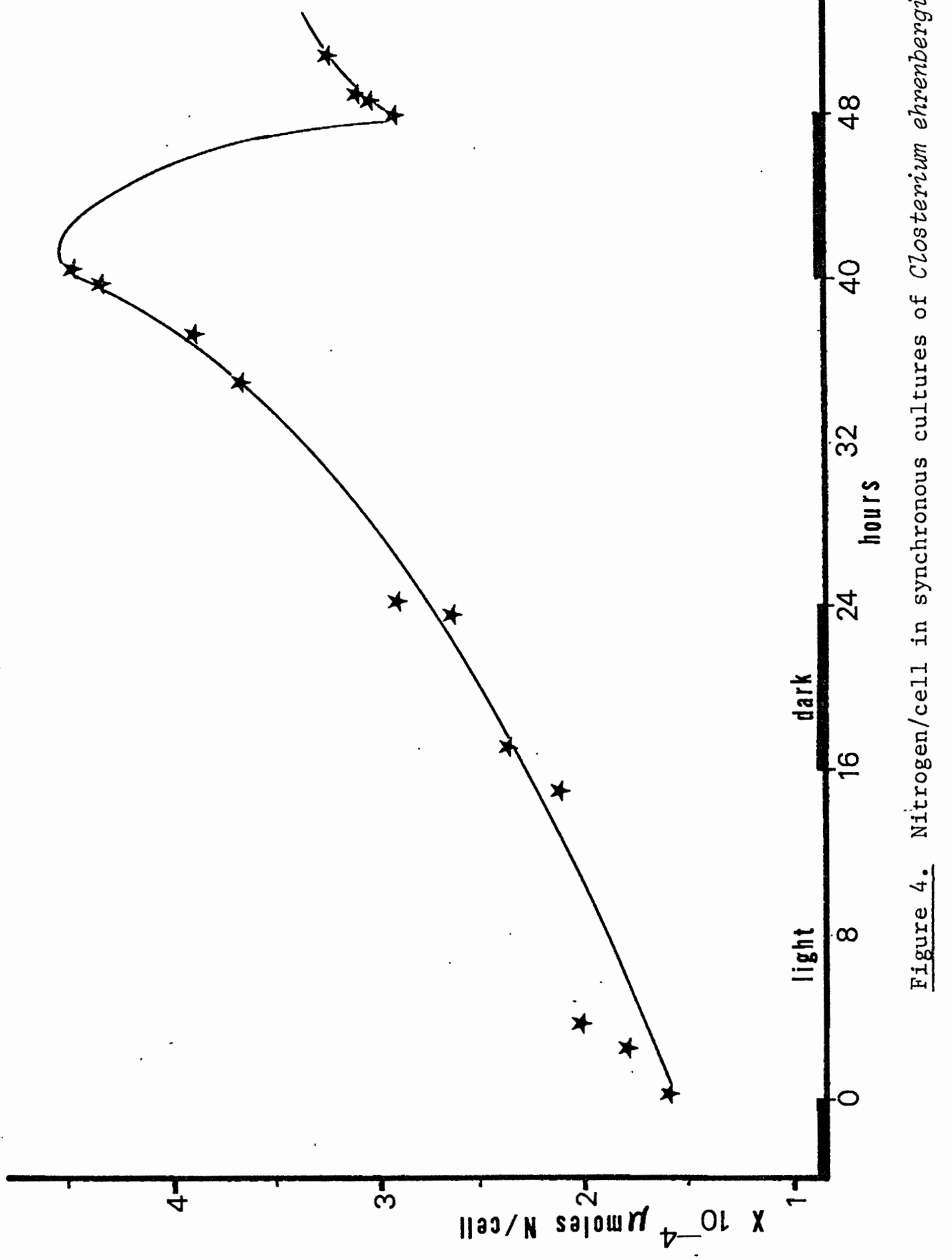


the cells in the culture. Cultures which have been nutrient deprived become synchronous when nutrients again are available. Because of this synchrony, the large fluctuation shown in Figure 4 is more representative of individual cell quota. About $40 \%$ of the cells divided during this dark period (i.e. cell division synchrony is $40 \%$ ). The lesser fluctuations in cell quota from later cell divisions (not shown in Figure 4) occur because cell division synchrony levels off at about $20 \%$.

Comparisons of the specific growth rate (k), taken as the difference in cell count on successive days with the average cell quota of strain $\# 3$ at the beginning of the dark period indicated a possible relationship between cellular nitrogen and cell division which may be independent of external nitrate concentration.

\section{SYNCHRONY}

Figure 5 shows a plot of time versus cell number and depicts the establishment of synchronous cell division in C. ehrenbergii (非15) by nitrate depletion. An examination of these results indicates:

1. That cell division continues after nitrate is depleted. This partitions out cellular nitrogen to daughter cells, resulting in lower cellular quota. The related results shown in Figure 4 show how cellular nitrogen varies after resumption of growth when nitrate is added.

2. Synchronous cell division occurs when nitrate is provided again. In my experience, this effect occurs most readily if the cells are held in stationary phase for 2 to 5 days. 


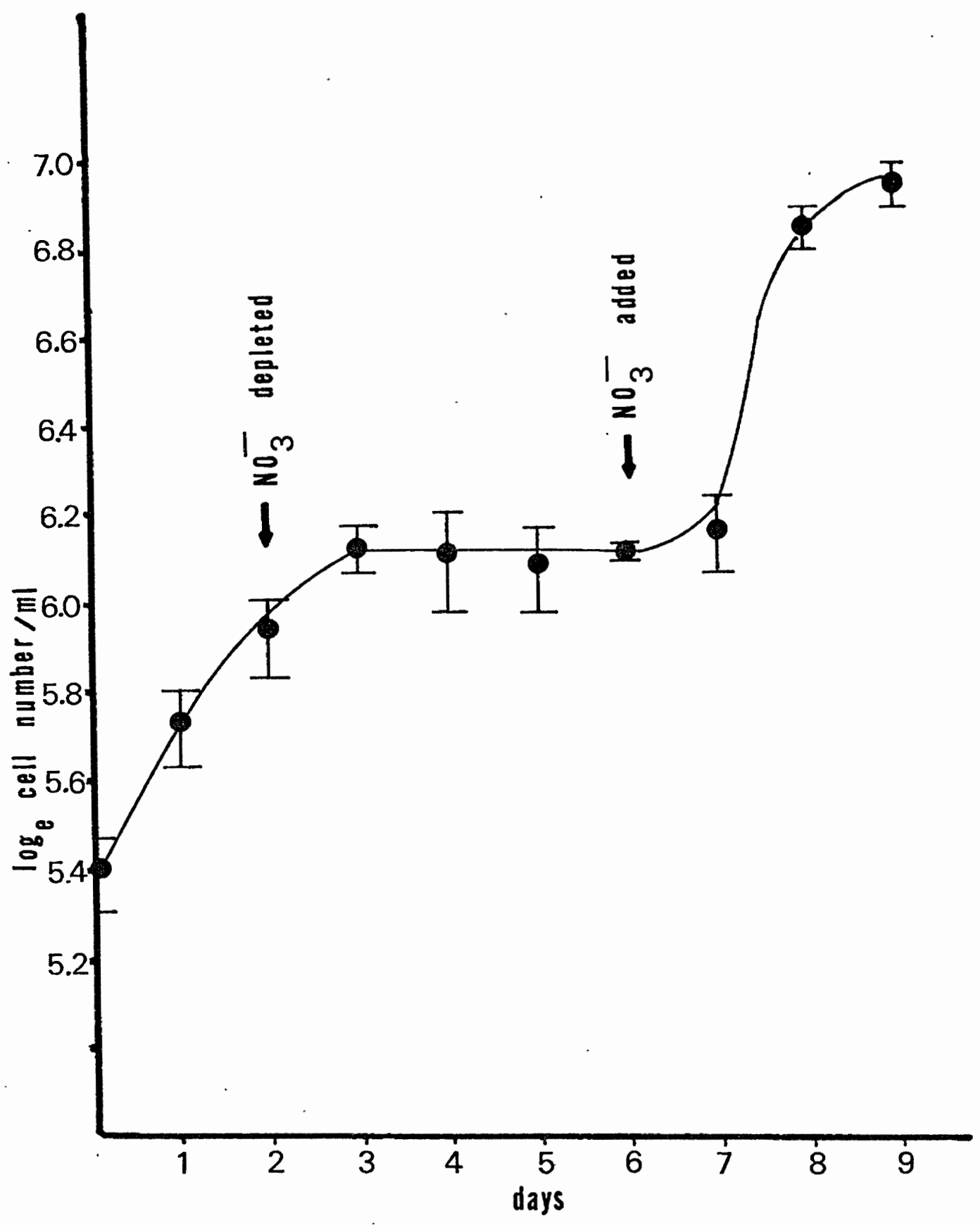

Figure 5. Synchronous cell division of Closterizm ehrenbergii (非15). 
Cells in stationary phase for longer periods of time gradually lose the ability to take up nitrate without long lag periods.

3. Enhanced synchrony of cell division occurs from day 7 to 8 , where $\mathrm{k}=0.95 \mathrm{divisions/day.} \mathrm{This} \mathrm{apparent} \mathrm{growth} \mathrm{rate,} \mathrm{as}$ determined from cell counts alone, is much higher than the real exponential growth rate. Synchronous cell division by nutrient depletion causes this anomaly in growth rate because cell counts are used as the measure of growth. In this case $65 \%$ of the cells divided between day 7 and 8 , so cell division is said to be $65 \%$ synchronous. The base level of synchronous cell division during exponential growth in this experiment was about $30 \%$ (day 0 to 2 , Figure 5). Since the generation time is about $2 \frac{1}{2}$ days under these conditions, the actual degree of synchrony is difficult to assess. If we assume that all cells in the culture grow at about the same rate, the actual synchrony would be somewhat higher than indicated. Cells growing on medium containing agar, where individual cells may be observed, occasionally divide at close to $100 \%$ synchrony for 3 to 4 cells divisions after innoculation of healthy single cells.

\section{UPTAKE KINETICS}

Figure 6 shows preliminary results on the rate of nitrate uptake by $C$. ehrenbergii relative to the concentration of nitrate in the medium. As can be seen, nitrate uptake rate is corrected for cellular 


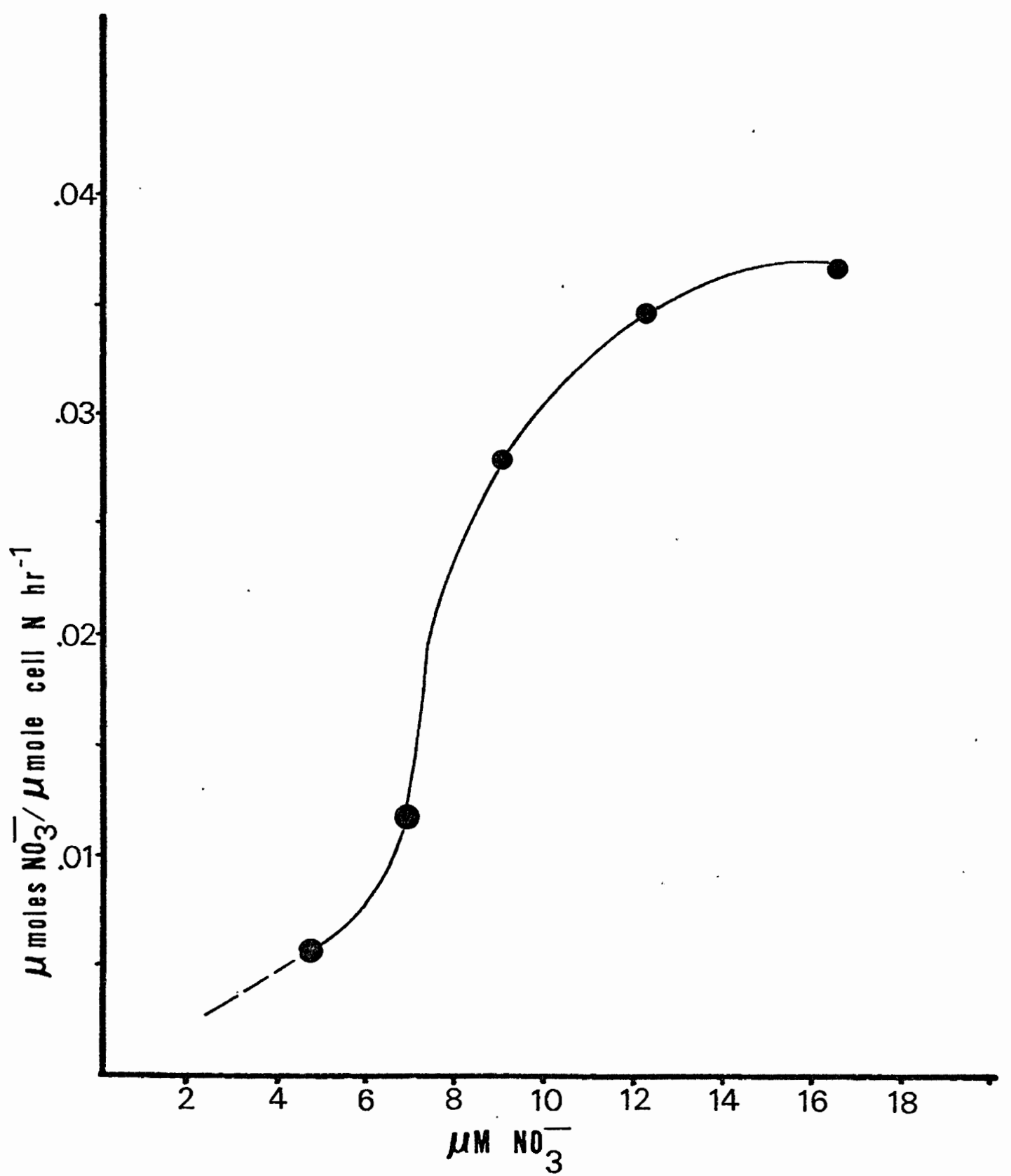

Figure 6. Nitrate uptake by Closterium ehrenbergii (非15). 
nitrogen to eliminate the effects of growth during the experiment. Since the results appear not to conform to the Michaelis-Menton hyperbola, no determination of a $\mathrm{K}_{\mathrm{m}}$ for uptake was attempted. 


\section{CONCLUSIONS}

These experiments, personal observation of natural distribution, and the results of other workers $(25,27,28)$ indicate that Closterium ehrenbergii grows well in alkaline waters, even at $\mathrm{pH}>9$. It is generally considered that the availability of free $\mathrm{CO}_{2}$ may be the limiting factor for growth of many algae at high $\mathrm{pH}(28,29)$. The ability of some species to continue growth at these $\mathrm{pH}$ may be due to their ability to utilize $\mathrm{HCO}_{3}$ as a carbon source for photosynthesis. The confirmed presence of carbonic anhydrase in some algae (29), which converts $\mathrm{HCO}_{3}^{-} \rightarrow \mathrm{CO}_{2}$ is strong evidence for this possibility. Another possibility is that these algae can take up sufficient $\mathrm{CO}_{2}$ from the very low concentrations present at these high $\mathrm{pH}$.

An optimum level of dissolved constituents was indicated by the experiment in which total salt concentration was varied. Since nitrate concentration varied with differences in total concentration of the medium, perhaps variation in nitrate concentration alone can explain the results of the total salt concentration experiment. My results seem to indicate that both an optimal nitrate concentration and an optimal total salt concentration for growth occur but the effects of each cannot be separated on the basis of these experiments. The work of both Moss (23) and Gough (25) is consistent with these results in indicating that the concentration of calcium ion is unlikely to affect the distribution of certain Closterium species in natural waters, although C. ehrenbergii was not used by these workers. They also 
indicated that many species of Closterium favor alkaline $\mathrm{pH}$.

The use of Tris buffered medium is not new. Ichimura (41) used $4.1 \times 10^{-3} \mathrm{M}$ Tris at $\mathrm{pH} 7.5$ for growth of Closterizon (see Appendix for Ichimura's Closterium medium). My results indicated that up to $10^{-2} \mathrm{M}$ Tris could be used without toxic effect, but that a higher $\mathrm{pH}$ (8.3 to 8.8) produced higher cell yields.

The induction of cell division synchrony by nutrient deprivation is discussed by Lorenzen and Hesse (47). The potential for error in the determination of exponential growth rates of desmids using cell counts for growth measurements, is compounded by synchronous effect. On the other hand, high levels of synchrony may allow a new approach to the effect of cellular nitrogen on cell division and on uptake of nitrate. In a completely snychronous culture, rates of nitrate uptake are indicative of uptake rates of single cells if uptake of nitrate is related to cellular nitrogen.

Experiments in synchronous cultures could be used to investigate the relationship between uptake rate and cellular nitrogen. The present experiments with uptake of nitrate and synchronous growth in a desmid suggest the possibility of such relationships as well as that between cellular nitrogen and cell division.

A survey of the literature did not reveal any reports of nutrient uptake studies with desmids. The kinetics of uptake by marine phytoplankton cultures has been extensively studied by many workers (48, 49, 50) in an ecological context. They have well documented the fact that open ocean species of phytoplankton, where nitrate concentration is very low, typically have lower $\mathrm{K}_{\mathrm{m}}$ for nitrate uptake than do estuarine 
and sublittoral species where nitrate concentration is usually higher. Differences in ability to take up nutrients at low concentrations are thought to be important variables determining distribution of various species.

Uptake of nitrate by marine phytoplankton typically can be described by the Michaelis-Menton hyperbola. This relationship implies the existence of a substrate-saturable component to the uptake system, like many transport and enzyme systems. Typical $\mathrm{K}_{\mathrm{m}}$ values for nitrate uptake by marine phytoplankton are 0.5 to $2.0 \mu \mathrm{M}$ nitrate. My results with $C$. ehrenbergii indicate a much lower affinity for nitrate as well as a non-hyperbolic expression for uptake at low concentrations. It may be that uptake of nitrate by this organism may be described by sigmoidal kinetics, possibly cause by interaction of the uptake (transport) system and the assimilation of nitrate via nitrate reductase. Although not reported here, preliminary results indicated that the three strains of Closterivo ehrenbergii used for these experiments could use urea or ammonia as sole nitrogen source, with approximately the same growth rates and yields as with nitrate nitrogen. Urea was toxic at concentrations greater than about $10^{-2} \mathrm{M}$. 
1. Mix, M. 1973. Die Feinstruktur der Zellwände der Conjugaten und ihre systematische Bedeutung. Beih. Nova Hedwigia 42:179-194.

2. Prescott, G.W., Croasdale, H.T. and Vinyard, W.C. 1972. A Synopsis of North American Desmids. Part I. Saccodermae, Mesotaeniaceae. North American Flora, Series II, part 6.

3: Prescott, G.W., Croasdale, H.T. and Vinyard, W.C. 1975. A Synopsis of North American Desmids, Part II, Section 1. Univ. of Nebraska Press, Lincoln.

4. Prescott, G.W., Croasdale, H.T. and Vinyard, W.C. 1977. A Synopsis of North American Desmids, Part II, Section 2. Univ. of Nebraska Press, Lincoln.

5! Bold, H.C. 1973. Morphology of Plants. Harper and Row Inc., New York.

6. Ihotský, 0. 1973. The production of chlamydospores in the genus Closterium (Desmidiaceae) in nature. Beih. Nova Hedwiga 42:163-169.

7. Brandham, P.E. 1965. The occurrence of parthenospores and other haploid resistant spores in Desmids. Trans. Amer. Micr. Soc. $\underline{84}: 478-484$.

8. Starr, R.C. 1955a. Asexual spores in Closterium didymotocum. New Phyto 1. $57: 187-190$.

9. Teiling, E. 1950. Radiation of desmids, its origin and its consequences as regards taxonomy and nomenclature. Bot. Not. 299-327.

10. Starr, R.C. 1955b. Isolation of sexual strains of placoderm desmids. Bulletin of the Torrey Botanical Club. 82:261-265.

11. Provasoli, L. and Carlucci, A.F. 1974. Vitamins and Growth Regulators. In Stewart, W.D.P. [Ed.] Algal Physiology and Biochemistry. U.C. Press, Los Angeles.

12. Biebel, P. 1973. Morphology and life cycles of saccoderm desmids in culture. Beih. Nova Hedwiga 42:39-57.

13. Lippert, B.E. 1967. Sexual reproduction in Closterizm monilifemm and Closterium ehrenbergii. J. Phycol. 3:182-198. 
14. Lippert, B.E. 1973. Some factors affecting conjugation in Closterium (Desmidiaceae). Beih. Nova Hedwiga 42:171-177.

15. Dring, M.J. 1974. Reproduction. In Stewart, W.D.P. [Ed.] Algal Physiology and Biochemistry. U.C. Press, Los Angeles.

16. Dubois-Tylski, M. 1972. Le cycle de Closterizon moniliferum in vitro. Bulletin Soc. Bot. Fr. 183-200.

17. Hoshaw, R.W. 1965. A cultural study of sexuality in Sirogonium melanosporum. J. Phycol. 1:134-138.

18. Pringsheim, E.G. 1949. Pure Cultures of Algae. Cambridge Univ. Press.

19. Moss B. 1973a. The influence of environmental factors on the distribution of freshwater algae: an experimental study. III. Effects of temperature, vitamin requirements and inorganic nitrogen compounds on growth. J. Ecol. 61:179-192.

20. Tassigny, M. 1971. Observations sur les bésoins en vitamines des Desmidiées (Chlorophycees-Zygnematales). J. Phycol. $7: 213-215$.

21. Czurda, V. 1926. Die Reinkultur von Conjugaten. Arch. Protistenk 53:215.

22. Hellebust, J.A. 1974. Extracellular Products. In Stewart, W.D.P. [Ed.] Algal Physiology and Biochemistry. U.C. Press, Los Angeles.

23. Moss, B. 1972. The influence of environmental factors on the distribution of freshwater algae: an experimental study. I. Introduction and the influence of calcium concentration. J. Ecol. 60:917-932.

24. Rodhe, W. 1958. Primärprodktion und Seetypen. Verh. int. Verein. theor. angew. Limnol: 10:377-386.

25. Gough, S.B. 1977. The growth of selected desmid (Desmidiales, Chlorophyta) taxa at different calcium and ph levels. Amer. J. Bot. 64:1297-1299.

26. Brook, A.J. 1965. Planktonic algae as indicators of lake types, with special reference to the Desmidiaceae. Limmol. and Ocean. 10:403-411.

27. Tassigny, M. 1973. Observations des variations qualitatives des populations de Desmidiées dans quelques étangs mésotrophes et dystrophes. Beih. Nova Hedwigia 42:283-316. 
28. Moss, B. 1973b. The influence of environmental factors on the distribution of freshwater algae: an experimental study. II. The role of $\mathrm{pH}$ and the carbon dioxide-bicarbonate system. J. Ecol. 61:157-177.

29. Raven, J.A. 1974. Carbon Dioxide Fixation. In Stewart, W.D.P. [Ed.] Algal Physiology and Biochemistry. U.C. Press, Los Angeles.

30. Waris, H. 1953. The significance for algae of chelating substances. Physiol. Plant. 6:538-543.

31. Gough, S.B. and Woelkerling, W.J. 1976. Wisconsin desmids II. Aufwuchs and plankton communities of selected soft water lakes, hard water lakes and calcareous spring ponds. Hydrobiologia 49:3-25.

32. Woelkerling, W.J. and Gough, S.B. 1976. Wisconsin desmids III. Desmid community composition and distribution relation to lake type and water chemistry. Hydrobiologia 51:3-32.

33. Moss, B. 1973c. The influence of environmental factors on the distribution of freshwater algae: an experimental study. IV. Growth of test species in natural lake waters, and conclusion. J. Ecol. 61:193-211.

34. Soeder, C.J. and Stengel, E. 1974. Physico-chemical factors affecting metabolism and growth rate. In Stewart, W.D.P. [Ed.] Algal Physiology and Biochemistry. U.C. Press, Los Angeles.

35. Brandham, P.E. and Godward, M.B.E. 1965. Mitotic peaks and mitotic time in the Desmidiaceae. Archiv. fur. Mikrobiologie 51:393-398.

36. Waris, H. 1950. Cytophysiological studies of Micrasterias I. Nuclear and cell division. Physiol. Plant. 3:1-16.

37. Schulle, H.H. 1973. Untersuchungen zum synchronen Zellwachstrum von Staurastrum pingue Teiling (Desmidiaceae) im LichtDunkel-Wechsel. Beih. Nova Hedwigia 42:275-281.

38. Provasoli, L. and Pintner, I.J. 1960. Artificial media for fresh water algae: Problems and suggestions. In Tryon, C.A. and Hartman, R.T. [Eds.] The Ecology of Algae. Edwards Brothers, Inc., Ann Arbor, Michigan.

39. Starr, R.C. 1954. Heterothallism in Cosmarium botrytis var. subtimidrom. Amer. J. Bot. 41:601-607.

40. Brandham, P.E. and Godward, M.B.E. 1964. The inheritance of mating types in desmids. New Phytologist 64:428-435. 
41. James, D.E. 1974. Culturing AZgae. Carolina Biological Supply Co. 非5-8192.

42. McLachlan, J. 1973. Growth media - marine. In Stein, J.R. [Ed.] Handbook of Phycological Methods. Cambridge. Univ. Press, London.

43. Sigma Technical Bulletin No. 106B, 1972.

44. Eppley, R.W. 1978. Nitrate Uptake. In Hellebust, J.A. and Craigie, J.S. [Eds.] Handbook of Phycological Methods. Cambridge Univ. Press, New York.

45. American Public Health Association. 1975. Standard Methods for the Examination of Water and Wastewater. 14th ed. American Public Health Association, New York, New York.

46. Guillard, R.R.L. 1973. Division Rates. In Stein, J.R. [Ed.] Handbook of Phycological Methods. Cambridge Univ. Press, London.

47. Lorenzen, H. and Hesse, M. 1974. Synchronous Cultures. In Stewart, W.D.P. [Ed.] Algal Physiology and Biochemistry. U.C. Press, Los Angeles.

48. Caperon, J. and Meyer, J. 1972. Nitrogen-1imited growth of marine phytoplankton. I. Changes in population characteristics with steady-state growth rate. Deep-Sea Research 19:601-618.

49. Caperon, J. and Meyer, J. 1972. Nitrogen-limited growth of marine phytoplankton. II. Uptake kinetics and their role in nutrient-limited growth of phytoplankton. Deep-Sea Research $19: 619-632$.

50. Eppley, R.W., Rogers, J.N. and McCarthy, J.J. 1969. Half-saturation constants for uptake of nitrate and ammonium by marine phytoplankton. Limnoz. Oceanogr. 14:912-920.

51. Nichols, H.W. 1973. Growth media - freshwater. In Stein, J.R. . [Ed.] Handbook of Phycological Methods. Cambridge Univ. Press, London.

52. Starr, R.C. 1960. The culture collection of algae at Indiana University. Amer. J. Bot. 47:67-86.

53. Provasoli, L. 1968. Media and prospects for cultivation of marine algae. In Watanabe, A. and Hattori, A. [Eds.] Cultures and collections of algae. Jap. Soc. Plant Physiol. 63-75. 
Chu 非10 medium (54)

$\begin{array}{lc}\mathrm{Ca}\left(\mathrm{NO}_{3}\right)_{2} & 40 \\ \mathrm{~K}_{2} \mathrm{HPO}_{4} & 5-10 \\ \mathrm{MgSO}_{4} \cdot 7 \mathrm{H}_{2} \mathrm{O} & 25 \\ \mathrm{Na}_{2} \mathrm{CO}_{3} & 20 \\ \mathrm{Na}_{2} \mathrm{SiO}_{3} & 25 \\ \mathrm{FeCl}_{3} & .8 \\ \mathrm{pH} 6.5-7.0 & \end{array}$

Pringsheim's Micrasterias medium (21)

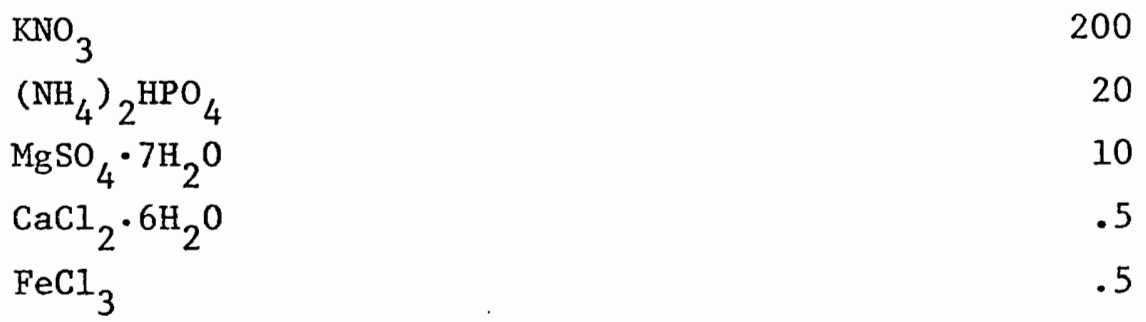

Pringsheim's desmid medium (55)

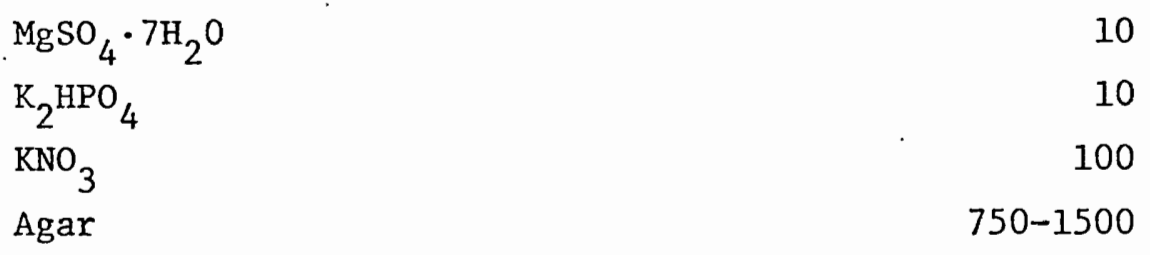

$50 \mathrm{ml} / 1$ soil-water supernatant

Kies vitamin solution (23)

${ }^{B}{ }_{12}$

thiamine

nicotinamide
$2 \times 10^{-4}$

$1 \times 10^{-3}$

$1 \times 10^{-4}$ 
PUBLISHED DESMID MEDIA (cont•)

Medium

Medium Reagents

Concentrations (mg/1)

Pringsheim's desmid medium (cont.)

PII trace metals (56)

$\begin{array}{lc}\text { Boron } & 2 \times 10^{-1} \\ \text { Fe } & 1 \times 10^{-2} \\ \text { Mn } & 1 \times 10^{-2} \\ \text { Zn } & 5 \times 10^{-3} \\ \text { Co } & 1\end{array}$

Iron sequestrine solution (54)

$\mathrm{FeSO}_{4} \cdot 7 \mathrm{H}_{2} \mathrm{O}$

5

EDTA

5.2

Waris solution (54)

$\mathrm{KNO}_{3}$

100

$\mathrm{MgSO}_{4} \cdot 7 \mathrm{H}_{2} \mathrm{O}$

20

$\left(\mathrm{NH}_{4}\right)_{2} \mathrm{HPO}_{4}$

20

$\mathrm{CaSO}_{4}$

50

Adjust $\mathrm{pH}$ to 6.0

M-3 medium (pers. comm. from W. Raymond, Washington State Univ.)

$\mathrm{KNO}_{3}$ 100

$\mathrm{Na}_{2}$ glycerophosphate 100

$\mathrm{MgSO}_{4} \cdot 7 \mathrm{H}_{2} \mathrm{O}$ 48

$\mathrm{CaCl}_{2} \cdot 2 \mathrm{H}_{2} \mathrm{O}$

PIV trace metals (44)

$$
\begin{aligned}
& \mathrm{Na}_{2} \mathrm{EDTA} \\
& \mathrm{FeCl}_{3} \cdot 6 \mathrm{H}_{2} \mathrm{O} \\
& \mathrm{MnCl}_{2} \cdot 4 \mathrm{H}_{2} \mathrm{O} \\
& \mathrm{ZnCl}_{2} \\
& \mathrm{CoCl}_{2} \cdot 6 \mathrm{H}_{2} \mathrm{O} \\
& \mathrm{Na}_{2} \mathrm{MOO}_{4}
\end{aligned}
$$$$
4.5
$$$$
582
$$$$
.246
$$$$
.030
$$$$
.012
$$$$
.024
$$ 
PUBLISHED DESMID MEDIA (cont.)

Medium

Medium Reagents

Bold's modified Bristol's solution (54)

$\mathrm{NaNO}_{3}$

250

$\mathrm{MgSO}_{4} \cdot 7 \mathrm{H}_{2} \mathrm{O}$

50

$\mathrm{K}_{2} \mathrm{HPO}_{4}$

100

$\mathrm{KH}_{2} \mathrm{PO}_{4}$

150

$\mathrm{CaCl}_{2}$

25

$\mathrm{NaCl}$

25

EDTA solution

EDTA

50

$\mathrm{KOH}$

26

$\mathrm{H}-\mathrm{Fe}$ solution

$\mathrm{FeSO}_{4} \cdot 7 \mathrm{H}_{2} \mathrm{O}$

(stock solution is made in : $1 \%$ con. $\mathrm{H}_{2} \mathrm{SO}_{4}$ )

Boron solution

$\mathrm{H}_{3} \mathrm{BO}_{3}$

11.4

H-H5 minor elements solution

$$
\begin{aligned}
& \mathrm{ZnSO}_{4} \cdot 7 \mathrm{H}_{2} \mathrm{O} \\
& \mathrm{MoO}_{3} \\
& \mathrm{Co}\left(\mathrm{NO}_{3}\right)_{2} \cdot 6 \mathrm{H}_{2} \mathrm{O} \\
& \mathrm{MnCl}_{2} \cdot 4 \mathrm{H}_{2} \mathrm{O} \\
& \mathrm{CuSO}_{4} \cdot 5 \mathrm{H}_{2} \mathrm{O}
\end{aligned}
$$

E.A. George's medium (43)

$\mathrm{KNO}_{3}$

$\mathrm{K}_{2} \mathrm{HPO}_{4}$

$\mathrm{MgSO}_{4} \cdot 7 \mathrm{H}_{2} \mathrm{O}$

ferric citrate

citric acid 
PUBLISHED DESMID MEDIA (cont.)

Medium

Medium Reagents

Ichimura's Closterium medium (44)

$\mathrm{KNO}_{3}$

$\mathrm{Ca}\left(\mathrm{NO}_{3}\right)_{2} \cdot 4 \mathrm{H}_{2} \mathrm{O}$

$\mathrm{MgSO}_{4} \cdot 7 \mathrm{H}_{2} \mathrm{O}$

$\mathrm{B}-\mathrm{Na}{ }_{2}$ glycerophosphate $\cdot 5 \mathrm{H}_{2} \mathrm{O}$

vitamin $\mathrm{B}_{12}$

Biotin

Thiamine-HCl

PIV trace metals

$$
\text { (see M-3 medium) }
$$

Tris buffer

500

Adjust $\mathrm{pH}$ to 7.5

Moss standard culture medium (26)

$\mathrm{Ca}\left(\mathrm{NO}_{3}\right)_{2} \cdot 4 \mathrm{H}_{2} \mathrm{O}$

$\mathrm{K}_{2} \mathrm{HPO}_{4}$

$\mathrm{MgSO}_{4} \cdot 7 \mathrm{H}_{2} \mathrm{O}$

$\mathrm{NaHCO}_{3}$

20

Trace element mixture

EDTA, tetrasodium salt

$\mathrm{FeCl}_{3} \cdot 6 \mathrm{H}_{2} \mathrm{O}$

$\mathrm{MnCl}_{2} \cdot 4 \mathrm{H}_{2} \mathrm{O}$

$\mathrm{ZnCl}_{2}$

.06

$\mathrm{CoCl}_{2} \cdot 6 \mathrm{H}_{2} \mathrm{O}$

$\mathrm{NaMoO}_{4} \cdot 2 \mathrm{H}_{2} \mathrm{O}$

.01

.012

.01

Vitamin mixture

Cyanocobalamin

$3.3 \times 10^{-5}$

Biotin

$3.3 \times 10^{-4}$

Thiamine-HCI

$3.3 \times 10^{-5}$

Adjust $\mathrm{pH}$ to $7.3-7.4$ 